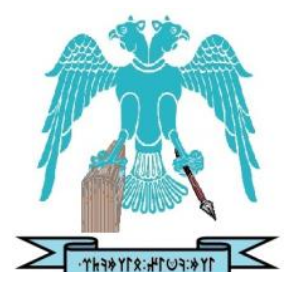

2602-2052
JOURNAL OF ENERGY SYSTEMS

VOLUME 3, ISSUE 2

DOI: $10.30521 /$ jes.565174

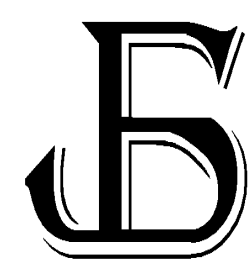

Research Article

\title{
Photovoltaic-Thermal solar energy system design for dairy industry
}

\author{
Gülşah Karaca (iD) \\ Gazi University, Ankara, Turkey, gulsahkaraca1@gmail.com \\ Ekin Can Dolgun (D) \\ Gemak Food Processing Mach., Ankara, Turkey, ekincandolgun@gmail.com \\ Meltem Koşan \\ Gazi University, Ankara, Turkey, polat.meltem@gazi.edu.tr \\ Mustafa Aktaş \\ Gazi University, Ankara, Turkey, mustafaaktas@gazi.edu.tr
}

Arrived: 14.05.2019 Accepted: 22.06.2019 Published: 30.06 .2019

\begin{abstract}
In 21th century demand for energy is rapidly increasing as the population is increased. To provide desirable living conditions and satisfy the food needs of overpopulated humanity getting harder and harder due to the limited energy and nutrient resources. Nutrient sources pass through many stages such as heating, cooling, drying and freezing which includes thermal and electrical energy needs before being presented to the consumer in the food industry. In the current situation, these two main energy requirements are largely met by fossil fuels which are not efficient, unsustainable and not user friendly in terms of resource management. In this context, the possibilities of usage Photovoltaic-Thermal (PV/T) solar energy systems which will be able to eliminate these disadvantages, use solar energy as a source and can meet the thermal and electrical requirements of the facility continuously has been investigated and, a system was designed which can meet the energy needs according to different scenarios for different processes. It is aimed to produce food in low carbon-emission facilities by meeting both electrical and thermal energy from the solar energy which is a renewable and clean energy source.
\end{abstract}

Keywords: Energy, Energy efficiency, PV/T design, Solar energy

Cite this paper as:

Karaca, G., Dolgun, EC., Koşan, M., Aktaş, M., Photovoltaic-Thermal solar energy system design for dairy industry, Journal of Energy Systems 3(2);(2019); 86-95, DOI: $10.30521 /$ jes. 565174

(C) 2019Published by peer-reviewed open access scientific journal, JES at DergiPark (www.dergipark.gov.tr/jes)

\begin{tabular}{|c|c|c|c|}
\hline \multicolumn{2}{|c|}{ Nomenclature } & \multicolumn{2}{|c|}{ Greek symbols } \\
\hline$A_{c}$ & Collecting area, $\left(\mathrm{m}^{2}\right)$ & $\eta_{P V}$ & Electrical efficiency, $(\%)$ \\
\hline$c_{p}$ & Specific heat of water, $(\mathrm{kJ} / \mathrm{kg} \mathrm{K})$ & $\eta_{t h}$ & Thermal efficiency, $(\%)$ \\
\hline$F_{R}$ & Heat gain factor & $\eta_{P V T}$ & PV/T collector efficiency, $(\%)$ \\
\hline$I_{G}$ & Global irradiance incident on solar collector, $\left(\mathrm{W} / \mathrm{m}^{2}\right)$ & $\tau \nu$ & Transparent cover transmittance \\
\hline$I$ & Solar irradiance, $\left(\mathrm{W} / \mathrm{m}^{2}\right)$ & $\alpha_{\text {abs }}$ & Effective permeability absorption coefficient \\
\hline$\dot{m}$ & Mass flow rate $(\mathrm{kg} / \mathrm{s})$ & & \\
\hline $\mathrm{T}_{\mathrm{a}}$ & Ambient temperature $(\mathrm{K})$ & & \\
\hline $\mathrm{T}_{\mathrm{i}}$ & Inlet fluid temperature of the collector $\left({ }^{\circ} \mathrm{C}\right)$ & & \\
\hline$\dot{Q}_{e}$ & Electrical Power, $(\mathrm{kW})$ & & \\
\hline$\dot{Q}_{t h}$ & Thermal Power, $(\mathrm{kW})$ & & \\
\hline$Q_{L}$ & Heat losses, $(\mathrm{kJ})$ & & \\
\hline$\dot{Q}_{u}$ & Total power of PV/T collector, $(\mathrm{kW})$ & & \\
\hline$U_{L}$ & Collector overall heat loss coefficient, $\left(\mathrm{W} / \mathrm{m}^{2}{ }^{\circ} \mathrm{C}\right)$ & & \\
\hline
\end{tabular}




\section{INTRODUCTION}

Nowadays, the demand for energy and food is increasing due to population growth and accordingly to this, the use of fossil fuels which are the primary energy resources such as petroleum, natural gas, and coal is rapidly increasing and, is becoming a major environmental problem and energy shortage. For this reason, it is understood by the whole world that sustainable use is required for the resources of the earth which has consumed with a great hunger and unconsciously in the past. Thus, the use of energy efficiently and the obtained from renewable energy sources have gained importance. Although renewable energy sources have a great energy potential, it is not possible to use the whole energy coming from the source completely but, it will be able to make this kind of use possible in the industry with new developing technologies and hybrid systems soon. Developments in the sustainable production of energy promise great hope and also, in many countries, these technologies are seen as a solution for a clean energy future.

In the near future, the sustainability of food production will be the most important issue for the food industry, which has a very important place in our daily lives and which includes intensive energy consumption. In the food production facilities, the product passes through many processes which includes thermal and electrical energy requirements such as drying, heating and cooling etc. As in other industries, in this industry, the needed energy is mostly met by from fossil fuels [1]. Turkey has more chance than the other countries in terms of solar energy potential due to its geographic situation. Solar radiation and sunshine duration in regions of Turkey is given in Table 1 according to "2017 Energy Report" published by World Energy Council-Turkish National Committee. Therefore, it is very significant to use of solar energy for energy consumption in the food industry; utilizing solar energy which is an inexhaustible, renewable and eco-friendly energy source will pull down the carbon emission rate by reducing the use of fossil resources.

Table 1. Solar radiation and sunshine duration in regions of Turkey [2]

\begin{tabular}{lcc}
\hline Region & Solar radiation $\left(\mathrm{kWh} / \mathrm{m}^{2}\right.$ year) & Sunshine duration (hours/year) \\
\hline Aegean & 1304 & 2738 \\
Marmara & 1168 & 2409 \\
Central Anatolia & 1314 & 2628 \\
East Anatolia & 1365 & 2664 \\
Southeast Anatolia & 1460 & 2993 \\
Mediterranean & 1390 & 2956 \\
Black Sea & 1120 & 1971 \\
\hline
\end{tabular}

There are two fundamental energy needs in the dairy industry, thermal and electrical energy. Processes like pasteurizing, evaporation, cooling, heating, freezing, washing and cleaning which require thermal energy do not require high temperatures $\left(<120^{\circ} \mathrm{C}\right)$ and can easily benefit from solar systems which have low maintenance and operating cost. Also, these systems can be used as a pre-heating process to achieve high temperatures and thus, usage of the resource can be reduced. At the same time, electrical energy which is utilized for motive loads (pumps, fans, blowers and lighting of facility, also cooling etc.) can be met by using PV/T systems.

By the technology using together thermal and photovoltaic collectors, hybrid systems which called as $\mathrm{PV} / \mathrm{T}$ have been developed which can meet the required thermal and electrical energy from solar. Photovoltaic (PV) solar cells are systems consisting of semiconductor materials which can convert solar energy directly into the electrical energy. Although $80 \%$ of solar radiation on the cell surfaces was reflected or turned into heat, the efficiency of the PV cells is ranging from $12 \%$ to $20 \%$ [3]. Moreover, every increase of $10{ }^{\circ} \mathrm{C}$ in the PV panel surfaces causes a decrease $5 \%$ electric efficiency in PV panels [4]. The PV/T systems have been developed in order to benefit from this heat energy that they collected on their surfaces by transferring to a fluid and transporting to the usage area or physical 
storage environment. In this way, the loss of efficiency of the PV cells is prevented at temperatures above the ideal operating temperature of the cells and the waste heat is made available and, many studies have already shown that this industry can take advantage of the commercially available temperature solar thermal collectors. However, it has been observed in the literature that mostly a single need (thermal or electrical) is met by using solar energy systems. Systems in which both thermal and electrical needs are met are rarely in the literature.

In cases where only the use of solar energy is not sufficient, the required energy can be met by combined heat pump system. Heat pumps are devices that make available to use by increasing the temperature of the energy which is available in nature which we cannot use because of lowtemperature without the need to burn any fuel. In cases the required electrical energy for compressor is generated from renewable energy sources, heat pumps can assume as a fully renewable energy technology. When the using PV/T and heat pump together, if the required electrical energy is met by $\mathrm{PV}$, it can be said that this hybrid system is a fully renewable energy system.

Schnitzer et al. (2007) stated that $80 \%$ of the required heating energy in the Austrian dairy industry can met by low temperatures $\left(60-80{ }^{\circ} \mathrm{C}\right)$ and, they indicated that the needed heat energy for dairy processes such as cleaning in place (CIP), preheating, pasteurization etc. can be met with using solar energy [5]. Benz et al. (1999) stated that with using solar energy, the required heat energy can be met for cleaning, pasteurizing, sterilizing and other operations in milk at medium temperature [6]. Desai et al. (2013) and Ekechukwu and Norton (1999) indicated that solar energy can be used as a preheating process for high temperature applications such as spray drying and sterilization in dairy industry. Thus, the heat load, cost and pollution of air can be decreased [7,8]. Date (2010) showed that with using PV, in dairy industry, the required electrical energy for pumping of chill water, CIP, water and product can be met [9].

From the given literature, it is figured out that many studies have been conducted relating with the $\mathrm{PV} / \mathrm{T}$ systems for industrial thermal applications for dairy processes. In this study, a hybrid heat pump assisted PV/T solar energy system was designed which can meet the required thermal and electrical energy for different processes and different scenarios throughout the food industry's production processes.

\section{PV/T SYSTEM DESIGN}

Figure 1. shows a schematic view of the hybrid PV/T system. This system consists of PV/T panels, a heat storage tank, a water source heat pump unit, heat exchangers, pumps, solenoid valves, and other elements. The heat collected from PV/T panels is transferred to the heat storage tank, which is the main element of the designed system. The electricity from PV/T can also be used as electricity in the facility or it can be converted into the heat energy with using heat pump technology. When the solar irradiation is not sufficient, the heat will be fed to the storage tank from another source (auxiliary heater) such as natural gas, coal etc. 


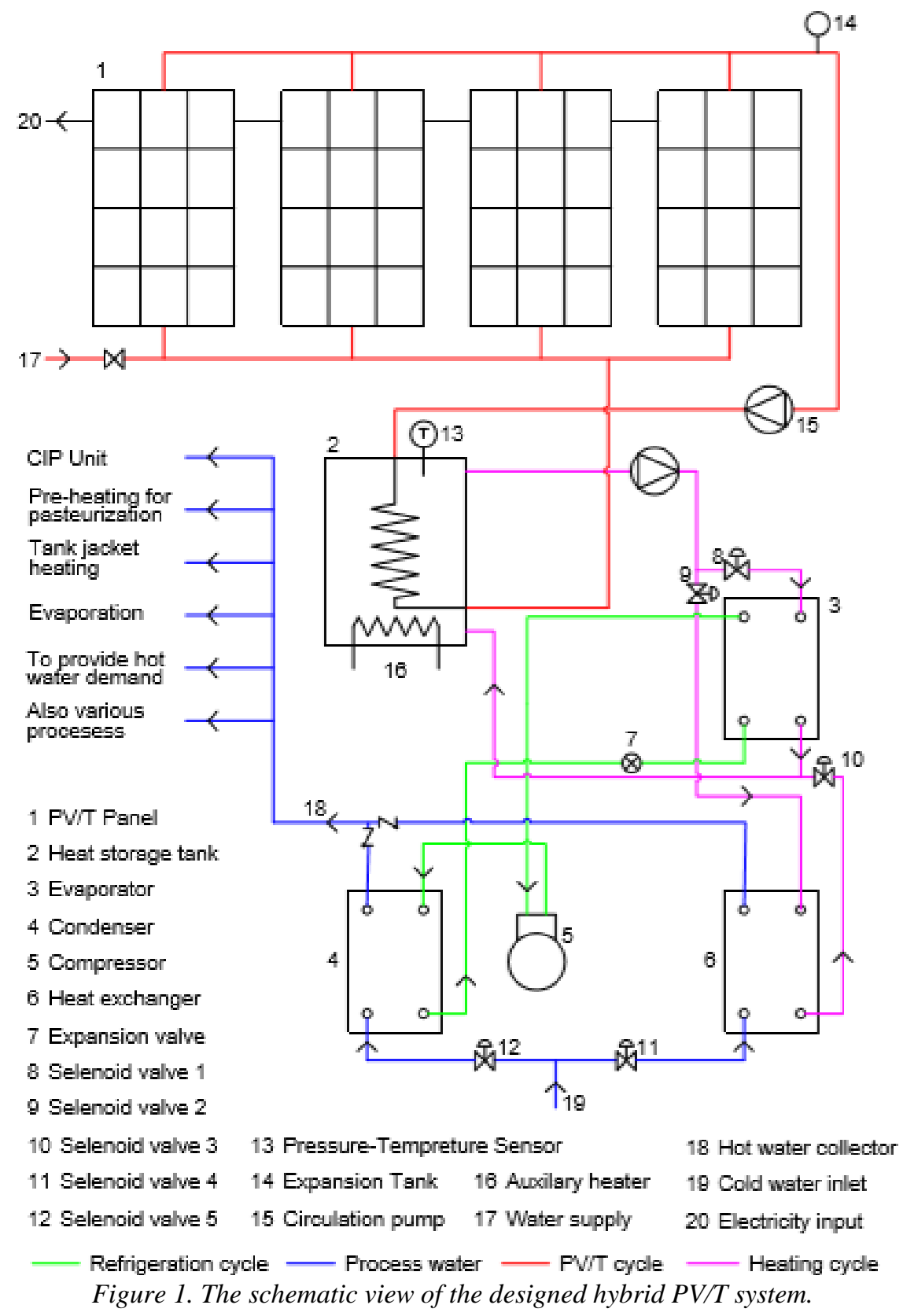

The system tank will operate automatically according to the following four different scenarios. At the stage of creating these scenarios, questions were asked about the operation of the designed system and scenarios were derived according to the answers received. The question-answer phase is given in Figure 2.

Scenario 1: When the benefit from sunlight is high, energy will be continuously collected in the heat storage tank due to closed cycle. In case of thermal need, the system will operate in the solenoid valve 2, 3, 4 open and solenoid valves 1 and 5 closed and, this accumulated high energy will be transferred to the system by means of a heat exchanger without running the heat pump and auxiliary heater. At the same time, the required electrical for motive loads can meet by the PV/T system.

When the water temperature in the heat storage tank is not enough for heating operation, there are two possibilities:

Scenario 2: Firstly, if the temperature of the heating medium in PV/T cycle is enough for evaporation temperature of the refrigerant; the heat exchanger "number 3 in Figure 1" can be used as an evaporator 
for heat pump system. The heat pump system will operate in the solenoid valve 1 and 5 open and solenoid valves 2, 3 and 4 closed and, according to COP value, the heat obtained from the PV/T is converted into useful heat through the condenser and fed to the system.

Scenario 3: Secondly, the required energy for evaporation temperature of refrigerant is met by an auxiliary heater and Scenario 2 continues to apply.

However, there is an important consideration here. Although food production processes require low temperature applications, there are different temperature values for different processes. However, if the condensate temperature of the heat pump cannot meet the desired process temperature:

Scenario 4: The energy required is provided by the auxiliary heater and Scenario 1 or Scenario $1 \& 2$ are applied simultaneously.

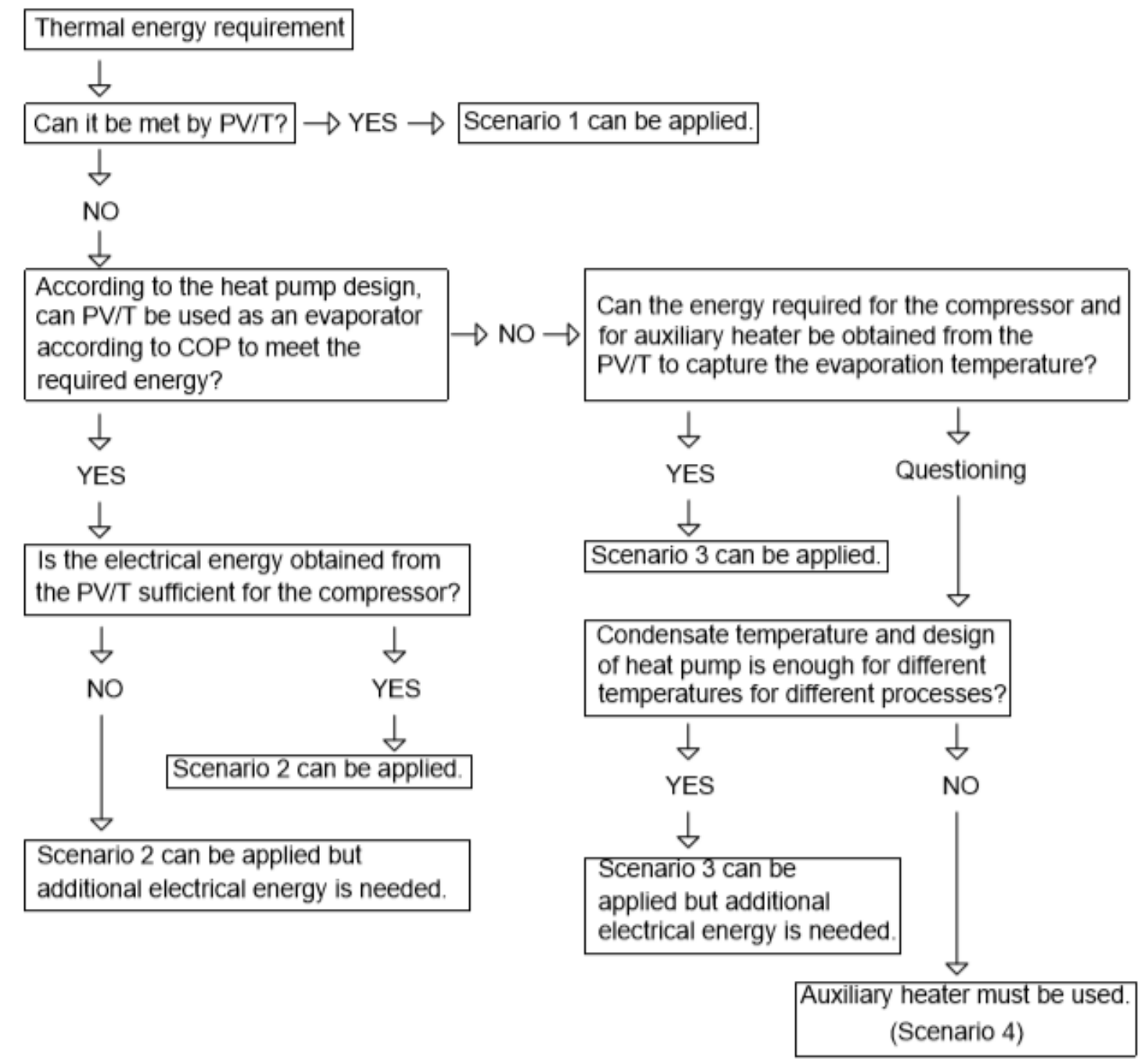

Figure 2. Question-answer phase diagram

The designed system can be operated continuously in the modes described above. According to temperature measurements in energy systems, heating and pre-heating process of food production systems can be done with using automatically control cycle. Consequently, a high rate of solar energy will be utilized. 


\section{EFFICIENCY ANALYSIS}

The implementation of the first law of thermodynamics on the PV/T panel which is combining both electrical and thermal components in a single unit area is shown in Figure 3. While solar energy converts into both electricity and heat, energy losses have also occurred. The overall system efficiency has constituted the efficiencies of electricity and heat.

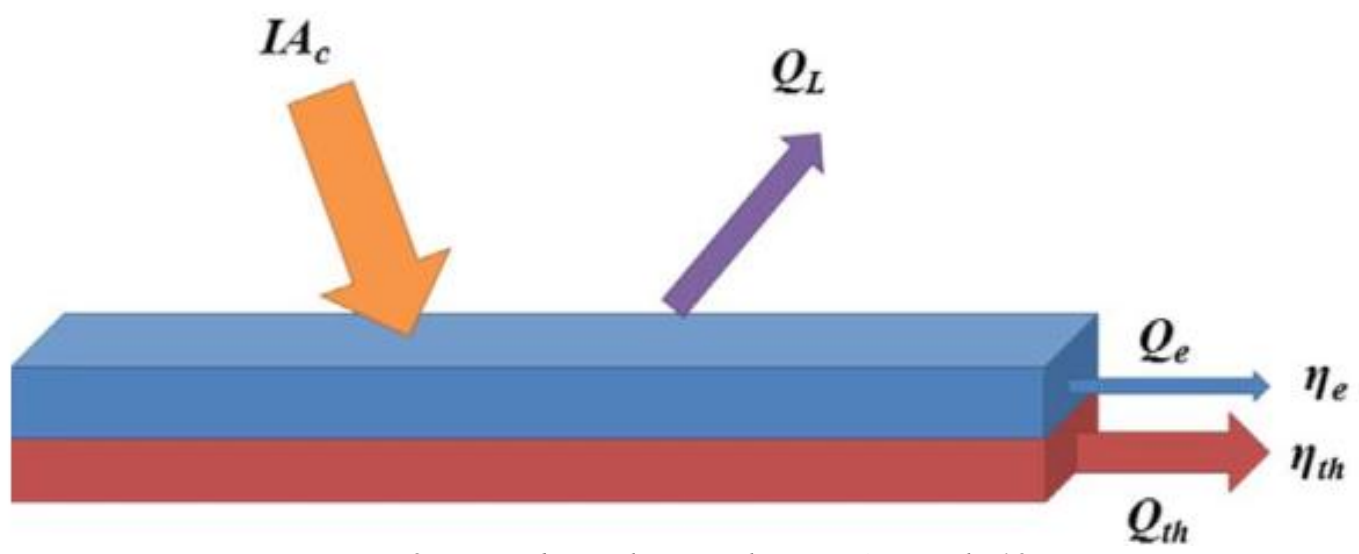

Figure 3. Basic thermal principle in PV/T panel [10].

The efficiency of PV panelcan be calculated by the following equation:

$$
\eta_{P V}=\frac{\dot{Q}_{e}}{I A_{c}}=\frac{I_{P V} U_{P V}}{I A_{c}}
$$

Thermal efficiency is the ratio of obtained energy to solar radiation. The efficiency of the solar collector is expressed as:

$$
\eta_{t h}=\frac{\dot{Q}_{t h}}{I A_{c}}=\frac{\dot{m} c_{p}\left(T_{o}-T_{i}\right)}{I A_{c}}
$$

The efficiency of the photovoltaic-thermal collector is given as follows:

$$
\eta_{P V, T}=\frac{\dot{Q}_{e}+\dot{Q}_{t h}}{I A_{c}}=\frac{\left(I_{P V} U_{P V}\right)+\dot{m} c_{p}\left(T_{o}-T_{i}\right)}{I A_{c}}
$$

The energy equation of the photovoltaic-thermal collectors can be written as:

$$
\dot{Q}_{u}=A_{c} F_{R}\left[I_{G}\left(\tau_{v} \alpha_{a b s}\right)-U_{L}\left(T_{i}-T_{a}\right)\right]
$$

Performance coefficient of the heat can be as written:

$$
C O P=\frac{\dot{Q}_{H}}{\dot{W}_{c}}
$$




\section{RESULTS}

The theoretical analysis of the presented design is based on the assumptions made in accordance with the information we have. The reason for this is that unless a case-study is carried out, talking about the scenarios 2,3 and 4 will not be possible. The reason is that the PV/T system will appear to meet all needs alone unless there is a limitation in the number of panels. This constraint can arise during actual application as usable roof space and/or economy.

A factory that processes $4.000 \mathrm{~L}$ of milk per day can be considered a medium-sized facility and, for a facility where frequently consumed products such as milk, yoghurt, cheese is produced, the area needed to carry out this production can be considered as approximately $300 \mathrm{~m}^{2}$ and the available roof area for usage of PV/T can be considered as approximately $150 \mathrm{~m}^{2}$.

Several dairy products were identified as examples for the analysis and, in the Table 2, the calculated thermal energy required for these products is given. The average solar radiation values were taken into consideration for Turkey and calculations for the products listed in Table 2 were carried out and, it was thought that all raw milk taken into the facility for each product is spent only for that product. Also, the studies conducted in the literature for thermal and electrical efficiency of water-based PV/T were examined and presented in Table 3. For theoretical analysis, these studies were taken as reference.

Table 2. Thermal energy consumption of processed milk

\begin{tabular}{llll}
\hline Raw milk & Product range & Quantity of milk required for production & Energy consumption \\
\hline \multirow{3}{*}{$4.000 \mathrm{~L}$} & Milk pasteurization & $1 \mathrm{~L} \mathrm{milk} /$ per kg & $6 \mathrm{kWh} / 100 \mathrm{~kg}$ \\
& Yoghurt & $1,6 \mathrm{~L} \mathrm{milk} /$ per kg & $82 \mathrm{kWh} / 100 \mathrm{~kg}$ \\
& White cheese & $8 \mathrm{~L} \mathrm{milk/per} \mathrm{kg}$ & $96 \mathrm{kWh} / 100 \mathrm{~kg}$ \\
& Mozzarella cheese & $7 \mathrm{~L} \mathrm{milk} /$ per kg & $65 \mathrm{kWh} / 100 \mathrm{~kg}$ \\
\hline
\end{tabular}

Cow's milk was taken as a reference. The values given in Table 2 can be changed according to production methods for facilities.

Table 3. Electrical and thermal efficiencies of PV/T collectors in the literature

\begin{tabular}{llllll}
\hline Ref. & Type of system & Nature of work & Electrical efficiency(\%) & Thermal efficiency (\%) & Year \\
\hline$[11]$ & PV/T- water+ air & Exp. & $8-11 \%$ & $40-55 \%$ & 2009 \\
{$[12]$} & PV/T- water & Exp. +Sim. & $12 \%$ & $50 \%$ & 2009 \\
{$[13]$} & PV/T- water & Exp. & $10 \%$ & $40 \%$ & 2011 \\
{$[14]$} & PV/T- water & Exp.+Sim. & $9 \%$ & $79 \%$ & 2011 \\
{$[15]$} & PV/T- water & Exp. +Sim & $15 \%$ & $50 \%$ & 2016 \\
{$[16]$} & PV/T- water+ air & Exp. & $17 \%$ & $76 \%$ & 2016 \\
\hline
\end{tabular}

In accordance with the literature, the thermal and electrical efficiencies for the calculations was accepted as 60 and $12 \%$, respectively.

As it can be seen from Table 4, the required thermal energy of most of the products given for the summer periods with the highest solar radiation can be met by the PV/T system. However, when the average solar radiation was taken into account, the PV/T system fully meets the energy required for pasteurized milk production only. It should be noted that: when the average data were used, more energy can be stored during midday hours was ignored. Although the facility does not produce continuously, the production process can be reviewed during the midday hours and energy storage can be done at the most efficient time. In addition, calculations of PV/T made on the basis of average of solar radiation of Turkey. For regions with higher radiation values depending on the location of the facility, these coverage rates will increase. 
Table 4. Scenario 1 calculations

\begin{tabular}{lccccc}
\hline Product range & Quantity & Thermal energy needed & Scenario 1* & Scenario 1** & Coverage ratio (\%)* \\
\hline Milk pasteurization & $4.000 \mathrm{~L}$ & $240 \mathrm{kWh}$ & & & 135 \\
Yoghurt & $2.500 \mathrm{~kg}$ & $2.050 \mathrm{kWh}$ & $324 \mathrm{kWh}$ & $702 \mathrm{kWh}$ & 16 \\
White cheese & $500 \mathrm{~kg}$ & $480 \mathrm{kWh}$ & & 67 \\
Mozzarella cheese & $570 \mathrm{~kg}$ & $370 \mathrm{kWh}$ & & & 87 \\
\hline
\end{tabular}

*Average solar radiation

** Maximum solar radiation

However, as mentioned above that all raw milk entering the facility is assumed to be used only in the production of one these products. Considering that different products will be produced during the daily production at the facility, the daily production energy requirement of these products will decrease and, it can be said that according to the share of raw milk, the thermal energy needed for all products listed above can be met by PV/T alone on a daily basis.

Calculations for Scenario 2, which is developed as an alternative application for cases where PV/T system is insufficient alone, are presented in the Table 5. When the PV/T system is used as an evaporator for heat pump system which has 0.9 isentropic efficiency, the useful heat gained from the condenser is given in the table. When the heat pump system is used, the required electrical energy for the compressor was calculated as $79 \mathrm{kWh}$.

Table 5. Scenario 2 calculations

\begin{tabular}{lcccc}
\hline \multicolumn{1}{c}{ Product range } & Scenario $1^{*}$ & Missing need & $\begin{array}{c}\text { When the energy obtained from PV/T } \\
\text { is used in the evaporator, the heat } \\
\text { gained from the condenser }\end{array}$ & $\begin{array}{c}\text { Coverage } \\
\text { ratio }(\%)^{* *}\end{array}$ \\
\hline Milk pasteurization & & - & & - \\
Yoghurt & $324 \mathrm{kWh}$ & $1.726 \mathrm{kWh}$ & $403 \mathrm{kWh}$ & 20 \\
White cheese & & $156 \mathrm{kWh}$ & & 84 \\
Mozzarella cheese & & $46 \mathrm{kWh}$ & & 108 \\
\hline *Average solar radiation & & &
\end{tabular}

*Average solar radiation

**In this calculation, it is assumed that the facility operates for 12 hours per day.

For PV/T, $65 \mathrm{kWh}$ of electrical energy can be produced with $12 \%$ electrical efficiency and, this means that $82 \%$ of the required electrical energy for the compressor can be obtained by PV/T. Scenario 2 achieves high coverage rates. However, in the case where Scenario 2 is also insufficient, to make a support to the thermal energy supplied from the PV/T, an external heater can be used and therefore, the energy required to obtain sufficient energy in the condenser can be provided (Scenario 3). The calculations for Scenario 3 are given in the Table 6.As mentioned, the total amount of energy required for the production of white cheese was calculated as $480 \mathrm{kWh}$. To achieve this value in the condenser, an evaporator of $386 \mathrm{kWh}$ is required. In fact, since $324 \mathrm{kWh}$ is supplied from PV/T, the missing 62 $\mathrm{kWh}$ of energy can be supplied by an auxiliary heater. Considering an auxiliary heater that is considered to operate at approximately $70 \%$ efficiency, there is an electrical energy requirement of $88.5 \mathrm{kWh}$ for this amount of thermal energy. Throughout the Scenario 3, the PV/T system can supply $40 \%$ of the total electrical energy needed. It should be noted again; as mentioned above, the daily production energy requirement of these products will decrease according to the share of raw milk. Accordingly, Scenario 2 and/or 3 can meet the required need without the need for an auxiliary heater. Also, the excess electrical energy stored during the implementation of Scenario 1 can then be used in Scenario 3.

As a continuation of Figure 3, it is necessary to use an external heater (Scenario 4) when Scenario 3 is not sufficient. 


\section{CONLUSIONS}

In this study, the availability of PV/T systems that can meet the necessary thermal and electrical energy during the production process of the food industry has been investigated and in this context a hybrid system has been designed to meet the need continuously and, four different application scenarios have been developed in order to meet the needs. At the stage of creating these scenarios, questions were asked about the operation of the designed system and scenarios were derived according to the answers received. With this designed PV/T system, heat can be gained from solar energy for low and medium temperature processes in the food industry, and there will be no threat to environmental pollution because renewable, clean energy source is used instead of fossil fuel. This system can operate with high performance even at low temperatures due to the water source heat pump technology. The required electricity for the compressor in the heat pump unit can be provided from the $\mathrm{PV} / \mathrm{T}$ panels. To get more efficient PV/T system, it is essential to cool the PV cell and decrease its temperature. Therefore, the efficiency of the PV panel can be increased up to 50-60\% with the combination of thermal application. The cost of installation of the PV/T system is lower than the installation cost of two separate systems, and also the total required area for PV/T panels occupies lower spaces.

Considering that the life of the energy source will exist for millions of years, it seems that it is inevitable to integrate these systems into the industry and to work on future technologies. While technology develops, lagging behind the systems, methods and insights used by the world, will cause irreparable results in terms of mutual cooperation, export/import, industry and technology.

\section{Acknowledgment}

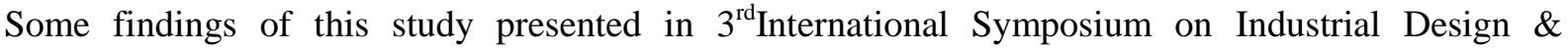
Engineering in Antalya / Turkey.

\section{REFERENCES}

[1] Purwanto A., Sušnik J., Suryadi F.X. and Fraiture C., Determining strategies for water, energy, and foodrelated sectors in local economic development, Sustainable Production and Consumption, 2018; 16: 16217.

[2] WECTNC (World Energy Council-Turkish National Committee), “2017 Energy Report”, Ankara, 2018.

[3] Abdelrazika A.S., Al-Sulaimana F.A., Saidurb R. and Ben-Mansou R., A review on recent development for the design and packaging of hybrid photovoltaic/thermal (PV/T) solar systems, Renewable and Sustainable Energy Reviews, 2018; 95: 110-129.

[4] Al-Waelia, A.H.A., Sopiana, K., Kazemb, H.A. and Chaichan, M.T., Photovoltaic/Thermal (PV/T) systems: Status and future prospects, Renewable and Sustainable Energy Reviews, 2017; 77: 109-130.

[5] Schnitzer, H., Brunner, C. and Gwehenberger, G., Minimizing greenhouse gas emissions through the application of solar thermal energy in industrial processes, Journal of Cleaner Production, 2007; 15: 1271 1286.

[6] Benz, N., Gut, M., Beikircher, T. and Russ, W., Solar process heat with non-concentrating collectors for food industry, In: Proceedings of ISES Solar World Congress, Jerusalem, Israel, 1999; 131-136.

[7] Desai, D.D., Raol, J.B., Patel, S. and Chauhan, I., Application of solar energy for sustainable dairy development, European Journal of Sustainable Development, 2013; 2(4): 131-140.

[8] Ekechukwu, O.V. and Norton, B., Review of solar-energy drying systems II: An overview of solar drying technology, Energy Conversion and Management, 1999; 40: 615-655. 
[9] Date, V., Financial feasibility of solar power project with reference to rural electrification of 39 talukas in Karnataka, Post Graduate, National Institute of Construction Management and Research (NICMAR), India, 2010 .

[10] Wu, J., Zhang, X., Shen, J., Wu, Y., Connelly, K., Yang, T., Tang, T., Xiao, M., Wei, Y., Jiang, K., Chen, C., Xu, P. and Wang, H., A review of thermal absorbers and their integration methods for the combined solar photovoltaic/thermal (PV/T) modules, Renewable and Sustainable Energy Review, 2017; 75: 839854.

[11] Dubey, S., Tiwari, G.N. Analysis of PV/T flat plate water collectors connected in series, Solar Energy 2009; 83(9): $1485-1498$.

[12] Ibrahim A., Othman, M.Y., Ruslan, M.H., Alghoul, M.A., Yahya, M., Zaharim, A. and Sopian, K., Performance of photovoltaic thermal collector (PVT) with different absorbers design. WSEAS Trans Environ Dev 2009; 5(3): 329-330.

[13] He, W., Zhang, Y. and Ji, J., Comparative experiment study on photovoltaic and thermal solar system under natural circulation of water, Applied Thermal Engineering, 2011; 31: 3369-3376.

[14] Dupeyrat, P., Mènèzo, C., Rommel, M. and Henning, H.M., Efficient single glazed flat plate photovoltaicthermal hybrid collector for domestic hot water system, Solar Energy 2011; 85: 1457-1468.

[15] Hazami, M., Riahi, A., Mehdaoui, F., Nouicer, O. and Farhat, A., Energetic and exergetic performances analysis of a PV/T (photovoltaic thermal) solar system tested and simulated under to Tunisian (North Africa) climatic conditions, Energy, 2016; 107: 78-94.

[16] Othman, M.Y., Hamid, S.A., Tabook, M.A.S., Sopian, K., Roslan, M.H. and Ibarahim, Z., Performance analysis of PV/T Combi with water and air heating system: An experimental study, Renewable Energy 2016, 86: 716-722. 